DOI : $10.14746 / \mathrm{pp} .2014 .19 .4 .17$

\title{
Michał M. Kosman, Polityka RFN wobec ZSRR/Rosji w latach 1989-2009, Wydawnictwo Uniwersytetu Kazimierza Wielkiego, Bydgoszcz 2013, ss. 563.
}

W roku 2013 na rynku wydawniczym ukazała się obszerna monografia dotycząca polityki Republiki Federalnej Niemiec wobec Federacji Rosyjskiej, uwzględniająca także stosunki z krajami Europy Środkowo-Wschodniej i całą przestrzenią postradziecką. Tej dogłębnej charakterystyki wzajemnych relacji od początku lat dziewięćdziesiątych XX wieku po pierwszą dekadę wieku XXI podjął się doświadczony w sprawach niemieckich młody pracownik naukowy Uniwersytetu Kazimierza Wielkiego w Bydgoszczy Michał M. Kosman. Należy zwrócić uwagę, że badana problematyka doskonale wpisuje się w obecne zainteresowania historyków i polityków, którzy próbują na nowo zdefiniować rolę Rosji na arenie międzynarodowej i zrozumieć promowane przez nią standardy polityki zagranicznej.

Cała praca została podzielona pod kątem problemowo-historycznym na sześć rozbudowanych rozdziałów, które chronologicznie omawiają kluczowe momenty polityki RFN wobec ZSRR/Rosji, płaszczyzny współpracy i spory polityczne od rozpoczęcia procesu zjednoczenia do końca rządów wielkiej koalicji CDU/CSU i FDP. Całość poprzedza rozbudowany wstęp, w którym Autor stawia szereg problemów badawczych natury szczegółowej, formułuje hipotezy i charakteryzuje specyficzną dla problematyki niemcoznawczej terminologię. Badania przesłanek polityki Bonn/Berlina względem Moskwy wymagały użycia wielu metod badawczych. W eksplanacji omawianych treści posłużono się przede wszystkim metodą historyczna, jak i statystyczną do zbadania rozmiarów dwustronnej wymiany handlowej, która umożliwiła skonstruowanie wniosków na temat rozmiaru dwustronnej wymiany handlowej. Słusznie posłużono się analizą instytucjonalno-prawną do przybliżenia kuluarów polityki niemieckiej ,ubranej” w podstawy traktatowe i akty prawne. Uwzględniając złożoność decydowania politycznego zastosowano analizy decyzyjne i behawioralne, które umożliwiły ocenę podejmowanych działań z uwzględnieniem indywidualnych motywów decydentów, ich cech przywódczych, oczekiwań społecznych i nastrojów panujących w ośrodkach decyzyjnych.

Pierwszy rozdział pracy należy traktować jako dłuższe wprowadzenie, gdyż nakreśla najważniejsze czynniki warunkujące kształt i formę wzajemnych relacji w oparciu o doświadczenia historyczne, wymogi bezpieczeństwa międzynarodowego i osobiste kontakty przywódców obu państw. Na uwagę zasługuje tu podrozdział na temat stosunków niemiecko-rosyjskich w kontekście relacji Unii Europejskiej z Moskwą oraz próba interpretacji kluczowych pojęć takich jak: partnerstwo pragmatyczne i strategiczne. Duże znaczenie w konstruowaniu pragmatycznego partnerstwa odegrały niemieckie prezydencje, które potwierdziły prymat unijnej solidarności i multilateralny charakter polityki niemieckiej wobec Rosji z rosnącym zrozumieniem dla wspólnej polityki energetycznej. Śledząc bezpośrednie kontakty Gerharda Schrödera z Władimirem Putinem i pragmatyzm jego następczyni Angeli Merkel, a także głosy politologów i debaty publiczne, Autor dochodzi do przekonania, że brak wspólnych wartości, podzielanych przez obie strony wyklucza sens budowania partnerstwa strategicznego, a utrwala raczej wspólnotę interesów.

Na tle całej pracy najbardziej kluczowe dla jej celu badawczego są rozdziały II i III. Skupiono się w nich na procesie jednoczenia Niemiec, pogłębiającym się rozpadzie rodziny państw socjalistycznych oraz rozbieżnościach pomiędzy linią reform Gorbaczowa a oczekiwaniami partnera wschodnioniemieckiego. Z dużą precyzją odniósł się Autor do kolejnych faz tego procesu uwzględniając zarówno aktywność dyplomatyczną w skali międzynarodowej, reakcje Bonn i Moskwy na exodus ludności wschodnioniemieckiej po zmierzch rządów Honeckera. Na tle tych wydarzeń wyłania się siła zabiegów kanclerza Kohla i aktywność dyplomacji zachodnioniemieckiej w „,kruszeniu” oponentów po stronie radzieckiej i polskiej. Pierwsze lata po październiku 1990 roku dominowały w wypracowywanie pozycji dla RFN, wyraźnie wzmocnionej terytorialnie i de- 
mograficznie oraz dla osłabionego i rozpadającego się imperium radzieckiego. Te poszukiwania umiejscowiono w procesach ogólnoeuropejskich i światowych w kontekście bezpieczeństwa międzynarodowego, o czym świadczy troska rządu federalnego o utrzymanie stabilności zarówno w ZSRR, na obszarze postradzieckim i w samej Rosji. Podpisane liczne umowy dwustronne, w tym traktat o dobrym sąsiedztwie, partnerstwie i współpracy oraz umocowanie Rosji w instytucjach międzynarodowych okazało się właściwym instrumentem dowartościowywania dysponenta potencjału nuklearnego, a zarazem utrzymania w jego polityce tendencji prozachodnich.

Na podstawie przedstawionych przez Autora wniosków i ocen końcowych można wysnuć bezpośrednią refleksję co do kalendarza stosunków niemiecko-radziecko/rosyjskich. Pierwsze w latach dwudziestego wieku zapoczątkowały nowy etap wzajemnych relacji. Oparte były one na wzajemnej empatii, pomocy finansowej, zrozumieniu niemieckich i rosyjskich interesów na arenie międzynarodowej, nie zapominając o relacjach personalnych między przywódcami, które na długo ukształtowały priorytetowe traktowanie Rosji w niemieckiej polityce wschodniej. Ten okres w sposób fundamentalny wpłynął na współczesną, jakże odmienną od polskiej percepcję Rosji przez elity niemieckie po zmianie przywództwa.

Druga połowa pracy została podzielona na trzy okresy, ściśle określone wyborami politycznymi, z których pierwszy obejmował czasy rządów CDU/CSU i FDP w latach 1994-1998, drugi dotyczył koalicji SPD-Zieloni pomiędzy 1998 a 2005 rokiem, a trzeci i ostatni prezentuje lata 2005-2009, gdy społeczeństwo niemieckie ponownie wybiera sprawdzoną wielokrotnie wielką koalicję czarno-czerwoną. Ta ostatnia doprowadziła nie tylko do depersonalizacji wzajemnych stosunków, ale także zaczęła uwzględniać interesy państw regionu środkowoeuropejskiego. Pierwszy gabinet Angeli Merkel wypełnił ten czas treściami aksjologicznymi w akcentowaniu problematyki praw człowieka oraz wypromował pragmatyzm w kontaktach gospodarczych.

Okres rządów chadecko-liberalnych w RFN, któremu poświęcono rozdział czwarty, zaznaczył się w historii relacji niemiecko-rosyjskich zmianą nastawienia i pogłębiania się różnic we wzajemnych rozmowach. Potwierdzają one tym samym nieprzewidywalność i fluktuację stosunków politycznych państw, które w zależności od dominacji określonych tendencji politycznych we władzach, jak i nastrojów społecznych, przybierają często nieoczekiwany obrót. Po stronie nierozwiązanych przez RFN kwestii znalazły się między innymi: brak porozumienia w kwestii zagarniętych z końcem drugiej wojny światowej niemieckich dóbr kultury, niemożność odtworzenia nadwołżańskiej autonomii. Za sukcesy strony niemieckiej uznał Autor powstrzymanie naporu migracyjnego Niemców rosyjskich, których problemy językowe i różnice kulturowe utrudniały asymilację w środowisku niemieckim. Przybliżono także meandry kształtowania nowego ładu bezpieczeństwa w Europie, gdzie Niemcy podjęły trud powolnego „oswajania” Rosji ze środkowoeuropejskimi dążeniami do członkostwa w Pakcie Północnoatlantyckim w osobach ministrów obrony Volkera Rühe, ministrów spraw zagranicznych Klausa Kinkela i Hansa Dietricha-Genschera. Na niwie bezpieczeństwa niezwykle ważnym akcentem okazało się, w dłuższej perspektywie, wspieranie i zacieśnianie stosunków Rosji z organizacjami międzynarodowymi, w tym Unią Europejską czy Grupą G-7.

Cezurę historyczną dla stosunków niemiecko-rosyjskich stanowiła porażka wyborcza CDU/CSU w wyborach do Bundestagu z 27 września 1998 i koniec szesnastoletnich rządów „kanclerza zjednoczenia" Helmuta Kohla. Rok później nastapił kres ery Jelcyna, twórcy niepodległej Federacji Rosyjskiej. Te dwa wydarzenia powiązane zmianami personalnymi nadały współpracy gospodarczej i dialogowi energetycznemu politycznych impulsów. Początkowa nieufność Zachodu ze względu na kryzys finansowy Rosji i wojnę czeczeńską przerodziła się w proces instytucjonalizacji współpracy gospodarczej, co Autor trafnie nazwał eufemistycznie „,pogłębianiem dialogu”. W tym fragmencie książki z dużą precyzją omówiono najważniejsze płaszczyzny stosunków dwustronnych.

Niebagatelne znaczenie dla wyzwań nowego milenium odegrała współpraca wojskowa i ścisłe związki Rosji z NATO, w tym otwartość strony rosyjskiej na rozszerzenie struktur Paktu Północ- 
noatlantyckiego w 1999 roku o Polskę, Czechy i Węgry oraz na misję stabilizacyjną ISAF w Afganistanie. Rola Niemiec we wpływaniu na powściagliwość Rosji w tych kwestiach jest nie do podważenia. Ważnym elementem kooperacji w dziedzinie wojskowości stały się plany współpracy techniczno-wojskowej w sferze uzbrojenia, jak i wspólne ćwiczenia czy szkolenia kadr. Ich symbolem były pierwsze od okresu międzywojennego wspólne manewry niemiecko-rosyjskie w sierpniu 2002 roku. Podpisano także umowy o zwalczaniu przestępczości, układy na temat pomocy prawnej w sprawach karnych i ekstradycji przestępców z 2001 roku, protokół dotyczący współpracy służb granicznych z lutego 2003 roku czy ułatwienia wizowe dla wybranych kategorii osób. Głównym elementem dialogu społecznego stał się utworzony z początkiem 2003 roku urząd koordynatora do spraw niemiecko-rosyjskiej współpracy społecznej. Pomimo tych wielu przychylnych gestów nie udało się rozwiązać sporu o niemieckie dobra kultury zagrabione podczas II wojny światowej, a wyraźna zmiana jakościowa i ilościowa w procesie wspierania Niemców rosyjskich zapoczątkowana przez gabinet SPD-Zieloni nie przyniosła oczekiwanych rezultatów. Efekty aktywności firm niemieckich na obszarze Petersburga były o wiele skromniejsze, niż się spodziewano, a kolejne komisje rządowe nie poprawiły statutu rosyjskich Niemców.

Kamieniem milowym polityki UE wobec Rosji stała się koncepcja tzw. czterech wspólnych przestrzeni, powstała na szczycie unijno-rosyjskim w Sankt Petersburgu w 2003 roku i doprecyzowana dwa lata później na szczycie w Moskwie. Śledząc opinie niemieckich badaczy na temat początkowego impasu we wzajemnych relacjach, spowodowanego animozjami wokół pomarańczowej rewolucji pod koniec 2004 roku, poprzez analizę różnic kulturowych i uwarunkowań historycznych udało się Autorowi znaleźć dowody na fundamentalny wkład strony niemieckiej w budowę wspólnej unijno-rosyjskiej przestrzeni współpracy. Rola adwokata Rosji w UE przełożyła się na likwidację wielu przeszkód w nawiązywaniu intensywniejszej niemiecko-rosyjskiej współpracy energetycznej, a wyjątkowo partnerskie relacje kanclerza Schrödera z prezydentem Putinem sprzyjały zawarciu umowy o budowie Gazociagu Północnego. Ze względu na wrażliwą dla sprawy polskiej materię prezentowanego tematu wskazany byłoby jego szersze omówienie.

Projekt ten można śmiało nazwać koniem trojańskim Rosji w „starych” krajach UE, który unaocznił różnice polityczne, historyczne między państwami członkowskimi UE. Do skali uzależnienia od rosyjskich dostaw gazu nie przywiązywano dużej wagi. W efekcie projekt zyskał wsparcie Komisji Europejskiej, która zakwalifikowała go jako składnik transgranicznych sieci europejskich, czym pogłębił podziały i ugruntował przedsięwzięcie jako jednoznacznie polityczne z zachowaniem własnych jednostkowych interesów.

Książka Michała Kosmana należy do pozycji historyczno-politologicznych, których znaczenia trudno nie docenić. Wpisuje się ona na trwałe w badania o charakterze ogólnoeuropejskim oraz prezentuje stosunki polityczne między ZSRR/Rosją i RFN na przełomie wieków. Lektura tej pozycji uświadamia wieloaspektowość i złożoność wzajemnych relacji, które w sposób pośredni kształtowały ogólne kierunki zmian polityki międzynarodowej w skali globalnej. Mnogość źródeł historycznych, przytaczane fakty i wypowiedzi potwierdzają trud politycznych negocjacji, dowartościowują sztukę dyplomacji, prowadzoną przez stronę niemiecką i każą powątpiewać w krótkotrwałe sukcesy negocjacyjne. Sformułowane przez Autora wnioski potwierdzają zaprezentowane wcześniej hipotezy i odpowiadają na postawione przez niego liczne pytania badawcze. O wadze tej monografii nie świadczy tylko pokaźna ilość prawie 600 stron, ale przede wszystkim zanalizowana literatura przedmiotu, tj.: obcojęzyczne prace naukowe głównie w języku niemieckim i rosyjskim, źródła pierwotne w postaci ustaw i dekretów, stenogramy z posiedzeń rządowych, a także pamiętniki przywódców politycznych, czasopisma naukowe poświęcone problematyce międzynarodowej oraz publikacje prasowe $\mathrm{i}$ internetowe. 